\title{
Mathematical model of evaluating the quality of "smart city" transport interchanges functioning
}

\author{
Margarita Panteleeva* and Svetlana Borozdina \\ Moscow State University of Civil Engineering, Yaroslavskoe shosse, 26, Moscow, 129337, Russia
}

\begin{abstract}
The analysis of government policy documents conducted by the authors allowed to establish that the Russian Federation Transport System Development Strategy until 2020, developed back in 2004, does not have a comprehensive and detailed toolkit for the implementation of all the goals and objectives presented in it, in particular, there are no current models of management decision-making at the Russian transport system development in a "smart city. The authors found that the effective management of traffic in a "smart city" should provide load transport network on the brink of its capacity and to maintain a continuous uniform motion, including the relatively low speeds, and increase the level of social development. This formulation of the problem proposed by the authors is fundamentally changing the construction of transport management systems, control algorithms and thus the model on which they are based, are not needed "smart city." Thus, the authors of the article developed a mathematical model for evaluating the efficiency of transport interchanges in the general system of transport development in the Russian Federation, taking into account the requirements of the "smart city" concept and the growing social effect.
\end{abstract}

\section{Introduction}

Today, the concept of "smart city" is used in many spheres of human activity, and its definitions are extremely diverse.

The simplest and most commonly used definition: Smart City - interconnected system of communication and information technologies with the Internet of Things (IoT), which simplifies management of internal city processes, and improves the standard of the population living [1].

Dr. Musa Sam of Maryland University, USA defines the "Smart City" as the concept of integrating multiple information and communication technologies (ICT) and the Internet of things (the IoT solutions) for City Property Management; city assets include, but are not limited to, local information systems departments, schools, libraries, transportation, hospitals, power plants, water supply and waste management systems, law enforcement, and other public services [2].

\footnotetext{
${ }^{*}$ Corresponding author: anteikom@yandex.ru
} 
One of the latest explanation of this concept has given by the Doctor of Technical Sciences, National Research MGSU Andrew A. Volkov ASG magazine article "Smart City: convergent socio-cyber-physical complex" 2018: Smart City - convergent socio-cyberphysical complex, whose parameter management processes are optimally adaptive to their own state space [1].

Obviously, this definition most accurately reflects the complexity of the urban environment, which is now closely linked to the population constantly changing needs and the ability of the environment and all its elements to independently adapt to them.

The main purpose of the "smart city" is to improve the population life quality by urban informatics technologies to improve the service efficiency and meet the needs of residents.

However, there remains the problem of an adequate analysis of the information received in terms of its personalization, timeliness and relevance. To successfully solve this problem, it is necessary not only to use artificial intelligence systems, but also well-developed and streamlined managerial decision-making models in a "smart city".

However, the identified issues have a very wide range of impacts on the functioning of a "smart city" and for its solution a differentiated approach is required with respect to each individual direction. The authors highlight the following structural element of "smart city" transport, since it was with the change of the transport system that the formation of the concept of "new city" began. To prove the need to develop additional tools for managing the development of the transport system of the "smart city", the authors of the article studied the statistics of the transport sector formation in Russia and countries of the world. It should immediately be noted that the following statistics, leaving the current state of the transport system is absolutely the opposite side in relation to the realized concept of "smart city". The analysis of the target indicators achieved in 2017 for Objective 1 of the Russian Federation transport system development strategy "Formation of a unified transport space of Russia based on balanced advanced development of an efficient transport infrastructure" demonstrates the positive dynamics of the Russian Federation transport industry development in terms of the unified transport space formation [3].

The total length of roads in our country as of 2018 was 1.66 million kilometers. Of these, only 1.16 million are paved roads. Such data leads Federal State Statistics Service of Russia. $7.3 \%$ of the total length is accounted for dirt tracks of federal, regional or intermunicipal value (Fig. 1).

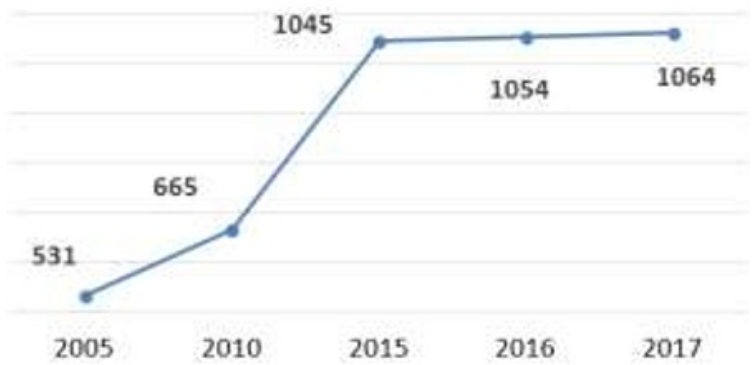

Fig. 1. Length of paved roads (including road junctions), thousand km [from website www.gks.ru Federal State Statistics Service of Russia].

Last year, Rosavtodor reported on the commissioning of 230.7 kilometers of new-built or reconstructed highways, of which about $6 \%$ relate to the reconstruction of road junctions, another 39 thousand kilometers are in normal condition. This year, the agency intends to complete work on another 146.6 kilometers of roads.

Obviously, this work is not enough, as Russia is inferior in density of the automobile network not only to developed countries, but also to many neighbors from the 
Commonwealth of Independent States, which does not correspond to the modern concept of a "smart city" and continues to support the old principles of managing this area.

A leader on this parameter, Japan, where 1,000 square kilometers accounts 3,250 kilometers of roads, of which $80.9 \%$ - a route paved. The second place is occupied by France with the result of 1932 kilometers, the United Kingdom (1733 kilometers) closes the top three. Moreover, in the last two countries the proportion of paved roads reaches one hundred percent.In our country, for every thousand square kilometers, there are only 87 kilometers of roads, of which only $70.6 \%$ of the hard surface is laid.

The issue of the cost of repair and maintenance of roads is also extremely difficult from a position of management in terms of development. This year, the maintenance and repair of highways from the federal budget laid 293.87 billion rubles, in the next two years the amount of funding will exceed 300 billion. In addition, about 20 billion rubles is annually allocated for the development of a network of regional, inter-municipal and local roads.

For Russian taxpayers, one kilometer of a strip costs 58.8 million rubles. So, experts say, the arithmetic average price of Russian roads is $1.4-2.8$ times less than in other countries with a similar climate.

The toll roads run by Avtodor in 2017 brought 8.9 billion rubles. Their total length across the country reached 815.6 kilometers. The Platon system, which collects a fee from heavy trucks for travel on federal highways, from November 2015 to May 2018 brought 47 billion rubles. According to official statistics, 1,7 thousand kilometers of roads were repaired with these funds [4].

Thus, in Russia today, the state of transport infrastructure and fixed assets of transport complex organizations is not adequate for the transition to "smart city", both in terms of technology and in terms of transport costs in the price of finished products, which now account for 20-25\%, which is higher than the level of developed countries by 2.5-3 times.

As a result, it is necessary to emphasize that the authors in various aspects analyzed the old decision-making models of the Russian Federation transport system development, but all of them showed that their performance is so low that it requires active management intervention to implement the "smart city" concept.

\section{Materials and Methods}

The determinant of further research was a set of state strategic documents:

1) Transport strategy of the Russian Federation for the period up to 2030 [5];

2) The state program of the Russian Federation "Development of the transport system" (2010 - 2020) [6];

3) The program of activities of the State Company "Russian Highways" for the long term (2010 - 2020) [7];

4) Development Strategy of the State Company Avtodor until 2030 [8].

5) The strategy of creating a network of highways and high-speed roads in the Russian Federation until 2030 [9, 10].

All of the above programs can, with varying degrees of maturity needed, evaluate the directions of the Russian Federation existing transport system modification. As the analysis of these documents showed, the strategic goal of the transport system modification is to meet the needs of an innovative, socially oriented economy and society development in competitive, high-quality transport services. If we concretize this formulation in the conditions of a "smart city", then we can say that the transport system of the Russian Federation is an important asset of the "smart city", which acts as one of the arteries of transmission and exchange of the resource potential of various urban agglomerations.

It is assumed that the transport industry at the turn of 2020 will become a backbone industry, and the achieved results should be qualitatively higher than those demonstrated by 
the analysis of statistical data conducted by the authors of the last ten years. The transport industry will compete in terms of specific transport costs, safety, environmental friendliness and quality of transport services. The level of developed countries will be reached in terms of commercial speed and timeliness of goods delivery, availability of transport services for the population. Formation of an integrated transport system of Russia and its integration into the global transport system will provide more efficient transport services within individual cities and the country as a whole, the growth in their exports, a more complete realization of the transit potential, meeting the needs of the economy and society as a qualitative and competitive transport services. That is, in the long term, it is assumed that the transport system will become a neural network between all system entities to peaples's life. Moreover, the main condition for creating such a unique network is its interoperability at various levels of functioning - the ability of some systems to independently interact with other systems. Moreover, in the case of the transport system, it is important that interoperability manifests itself not only at the technical level, which is a fully achieved characteristic of modern highways today with the help of clear standardization, but also at the social, organizational and regulatory (state) levels.

However, to achieve at least partial interoperability of the "smart city" transport system within the framework of the "Transport Strategy of the Russian Federation until 2020", it is necessary to define clear criteria for its assessment, which is extremely difficult to do, given that the resulting social effect from all the measures taken will be the resulting factor.

Today, the first steps have been taken in the development of methodological approaches to determine the social effect that cannot be directly valued, a critical analysis of which, conducted by the authors, showed that:

- generalized method of scoring the social development level [11], takes into account only the population of the area under consideration and changes in the scoring of the social sphere development level with the achieved and initial state of the road network. The process is highly subjective and does not allow to take into account the dynamics of the majority of factors affecting the livelihoods of citizens;

- the decomposition method [12], based on the use of the smallest unit criterion or discounted costs for improving the transport infrastructure and improving the quality of transport services in the calculation of the social outcomes weighted average score. At the same time, for the scoring of a specific social result, a set of social consequences determining the social effect is taken into account, and for each of them experts determine the specific importance in the complex. The global minus of the considered method is the lack of clear criteria for the decomposition of the transport infrastructure, which leads to a lack of uniformity in assessing the social effect of this method in various regions of the Russian Federation;

- the indirect social impact assessment method [12] uses the "social priority" indicator for the road project assessment, which is determined by multifactorial regression modeling of socio-economic factors affecting the development of the road network. This method uses a simple correlation model based on the results of an urban citizen's survey on satisfaction with various factors of their livelihoods. This correlation model does not allow to assess the existence of a real relationship between all the factors affecting livelihoods, there is only a mathematical justification and that's all;

- graphical method of the road conditions assessing impact on the level of non-transport socio-economic losses [13]. This method allows only approximately to determine the amount of non-transport socio-economic damage on the basis of special nomograms, which determine the dependence of the road network development level using only two indicators: the quality of transport services and the population of the region, which is clearly not enough for a deep assessment of the social effect; 
- evaluation method "living standards" [14]. It is used to establish the relationship between the security roads and the standard of living. The minus of the method lies in the territorial limitations of the analysis performed - the standard of living and the transport and economic security of individual regions or cities are assessed - which does not allow a systematic look at the problem in the country as a whole.

Summing up the preliminary results of the author's research it should be noted that for the implementation of the RF Transport Development Program until 2020 is necessary to achieve a much higher-quality results than existing revealed comparative statistics to date state of the Russian transport industry. Given the fact that the criterion for evaluating the effectiveness of the implemented changes in the transport system is the future social impact, the authors identified and critically analyzed the main methods used in practice to evaluate it. The analysis showed that the methods for assessing the social impact does not allow to take into account all the criteria and parameters functioning of the transport system in different regions, which requires the development of additional tools.

Generalization and systematization of all the above elements, and methods to assess the social impact of developing the transport system allowed the authors of the article developed the algorithm simulation process management Transport System Project (Fig. 2).

\section{Results}

The author's algorithm for modeling the project management process of changing the transport system (Fig. 2) consists of three main blocks: a control unit block describing the elements of a "smart city"; block management tools, characterizing official documents in the direction of the Russian Federation transport system development; block elements of the Russian Federation transport system development model, characterizing all the elements included in the Russian Federation transport system development model.

As an object of management in the author's model, the "smart city" is considered directly, which is a system of a city property management, which today includes many elements, on a level with which the transport system.

On the basis of the Russian Federation Government Order of November 22, 2008 N 1734p "On Approval of the Russian Federation Transport Strategy for the Period up to 2030 (with changes on May 12, 2018)" three basic components were chosen to create an effective competitive transport system (Fig. 2):

1) competitive high-quality transportation services in a "smart city";

2) high-performance safe vehicles and transport infrastructure of the "smart city";

3) competitive environment of the "smart city" (conditions for exceeding the level of supply of transport services over demand) (Fig. 2).

These elements allowed into account of the Russian State Program "Development of Transport System" (2010 - 2020) [6] to describe a transport system development model based on five actively modified elements: space transport, transport services, transit potential, safety, environmental friendliness. In this regard, it should be noted that all the elements of the model are a chain of interrelated processes that, with varying degrees of intensity, affect the project's lifecycle transport system changes (modifications), and, therefore, from different positions create conditions for the system increasing efficiency effect formation oriented on the result - on the growth of the urban population life quality.

To manage each element of the Russian Federation Transport System Development Model, it is necessary to have a set of management tools that, at all stages of the transport system change project lifecycle, will allow you to quickly and timely determine the quality of the planned and executed processes. As one of the tools of such a set, the authors of the article propose a "Model of expert assessment of the quality of functioning of a "smart city" $[15,16,17,18,19]$ transport junction", which allows using the selection of a specific set of 
adjustable parameters (allocated, selected, created for each object individually) to achieve the necessary quantitative performance indicators identified in the Russian Federation Transport System Development Program.

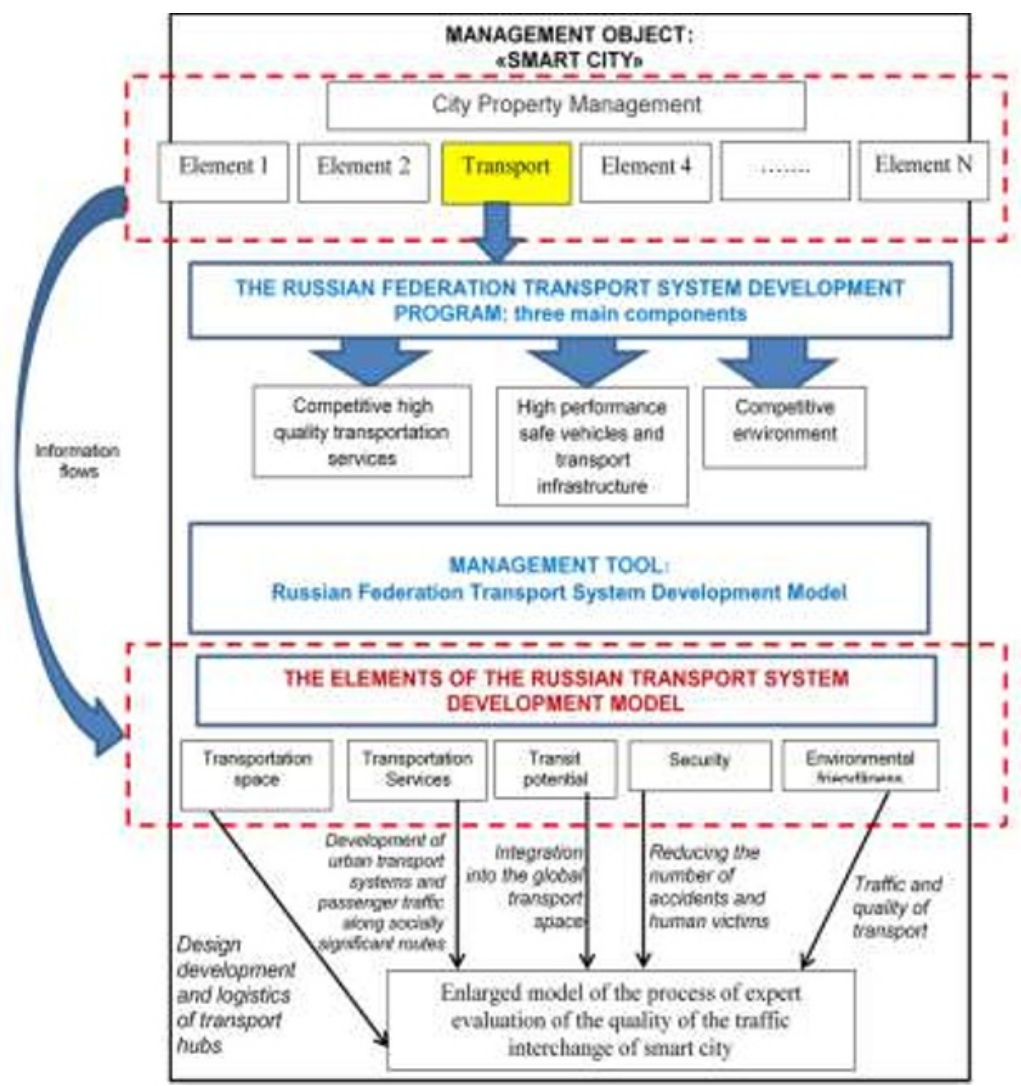

Fig. 2. Algorithm simulation project management process changes of the transport system in a "smart city" [created by the authors].

The author's «Model of expert assessment of the quality of functioning of a "smart city" transport junction» consists of five logically interconnected blocks that characterize the main processes used to create a pilot project of the road junction.

Each block represents a separate scope of the proposed author's model:

Block 1 "Object". It consists of a control object [Ob], which is represented by a traffic intersection, and a real control object [D], which is represented by the traffic interchange users.

In the case under study, the following were chosen as users of the interchange: $\mathrm{Q}$ - the number of transport units; $\mathrm{f}$ is the frequency of the junction use or its passability; $\mathrm{P}$ - cost of the junction operation for users; $\mathrm{Ob}$ - transport interchange as a control object.

Block 2 "Parametric". This block allows you to identify and determine the value of the adjustable parameters that affect the quality of the junction. All parameters are divided into two groups: technical and economic, and represent the means of isolating and changing the composition of the controlled parameters.

Block 3 "Expert". Within this block, an expert assessment process is presented, consisting of four subprocesses of the quality of the functioning of the traffic interchange. 
Block 4 - "Legal". Within the framework of this block an implicit contract is formed which controls the institutional framework of the projects being created for traffic interchange.

Block 5. "Managerial". It allows you to create a strategy and tactics for the formation of projects for the transport interchange of a "smart city" based on the selection of macronutrients of a high-quality functioning transport system.

The main purpose of the Block 5 «Models of the process of expert evaluation of the quality of functioning of the transport interchange "smart city"» modified release formulation of the problem in macro-quality operating system, which is replaced by a complex system of specific indicators of efficiency of functioning of the transport system of the Program of transport system development of Russia.

As a result, it can be stated that the main expected results of the implementation of these programs should be reflected in four the Russian Federation citizens' life areas: the environmental sphere; the economic sphere; public administration; social sphere.

Therefore, the authors of the article propose to evaluate the efficiency of the Russian Federation transport system functioning through the final effects specified in the Transport Development Program: social, commercial and budgetary. For this purpose the authors formed the relationship diagram all three effects (Fig. 3).

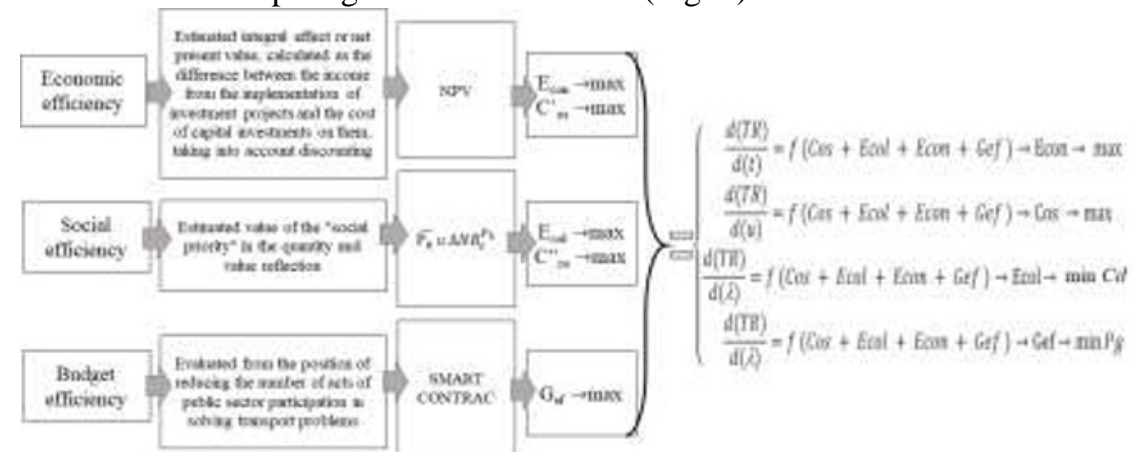

Fig. 3. Diagram showing the relationship of economic, social and budgetary effects and the mathematical model of an estimation of quality of the transport interchange «smart city» functioning [created by the authors].

Each effect is considered in the framework of the corresponding efficiency system, which has its own parametric data and the expected qualitative results. Systems of this kind in mathematical economics are called dynamic and for their solution a scenario approach is used to evaluate the possible development strategy of each system by playing different scenarios based on the chosen mathematical model using different sets of economic parameters and analyzing the resulting decisions.

Most of the dynamic systems [20], including the country junction system, after some transformations can be represented by the following non-linear ordinary differential equations systems (1):

$$
\frac{d x}{d t}=f(x, u, \lambda), x\left(t_{0}\right)=x_{0}
$$

where $x=\left(x^{1}, x^{2}, \ldots \ldots, x^{n}\right) \in X \subset R^{n}$ is the state vector of the transport system; $u=\left(u^{1}, u^{2}, \ldots \ldots, u^{l}\right) \in W \subset R^{l} \quad$ - vector of controlled (adjustable) parameters of the transport system $\mathrm{W}, \mathrm{X}$ - compact sets with non-empty interiors - $\operatorname{Int}(\mathrm{W})$ and $\operatorname{Int}(\mathrm{X})$ respectively; $\lambda=\left(\lambda^{1}, \lambda^{2}, \ldots ., \lambda^{m}\right) \in \Lambda \subset R^{m}$ is the vector of uncontrolled parameters; $\Lambda$ is an open connected set of parameters of the mapping $f(x, u, \lambda): X * W * \Lambda \rightarrow R^{n}$ и $\frac{d x}{d t}, \frac{d x}{d u}, \frac{d x}{d \lambda}$ are continuous in $X * W * \Lambda ;\left[\left(t_{0}\right),\left(t_{0}\right)+T\right]$ is a fixed period of time. 
As is known, the solution of the considered system of ordinary differential equations depends both on the vector of initial values $\mathrm{x}_{0} \in \operatorname{Int}(\mathrm{X})$, as well as on the values of the vectors of controlled $(\mathrm{u})$ and uncontrolled $((\lambda)$ parameters. Therefore, the result of the development (change) of a nonlinear dynamic system for a given vector of initial values $\mathrm{x}_{0}$ is determined by the values of the vectors of both controlled and uncontrolled parameters.

It is also known that in order to judge by the decisions of the system about the object described by it, this system must have the property of immutability of the qualitative picture of trajectories with small perturbations of the right side of system (1) in some sense. In other words, system (1) must have the property of coarseness, or structural stability.

As part of the problem to be solved evaluating the performance of the transport interchange in the system of "smart city" offers a system of equations (1) represented as follows (2):

$$
\left\{\begin{array}{l}
\frac{d(T R)}{d(t)}=f(\text { Cos }+ \text { Ecol }+ \text { Econ }+ \text { Gef }) \rightarrow \text { Econ } \rightarrow \text { max } \\
\frac{d(T R)}{d(u)}=f(\text { Cos }+ \text { Ecol }+ \text { Econ }+ \text { Gef }) \rightarrow \text { Cos } \rightarrow \text { max } \\
\frac{d(T R)}{d(\lambda)}=f(\text { Cos }+ \text { Ecol }+ \text { Econ }+ \text { Gef }) \rightarrow \text { Ecol } \rightarrow \text { min Cd } \\
\frac{d(T R)}{d(\lambda)}=f(\text { Cos }+ \text { Ecol }+ \text { Econ }+ \text { Gef }) \rightarrow \text { Gef } \rightarrow \text { min Pg }
\end{array}\right.
$$

Where $\overrightarrow{\boldsymbol{T R}}=f\left(C_{o s}+E_{c o l}+E_{c o n}+G_{e f}\right)$ is the state vector of the transport system; $P g$ - the number of acts of state participation; $C d$ - the cost of the damage; Econ - economic effect; Cos - social effect; Ecol - environmental impact; Gef - the effect of public administration.

Further, in order to calculate the social effect in a scaled (dimensionless) form, the authors propose to quantify the "social priority" indicator, which in our case will be an indicator of road provision in various regions of the country:

$$
\widehat{P_{k}}=a_{k}+d_{k} * \overrightarrow{\mathbf{P}_{\mathbf{k}}}
$$

where $\left(\mathrm{P}_{-} \mathrm{k}\right)^{\wedge}$ is the indicator of road security of the $\mathrm{k}$-th subject of the Russian Federation; $a k, d k-\overline{s c a l i n g}$ factors for the $k$-th subject of the Russian Federation. Values $a k, d k$ are determined by the formulas:

$$
\begin{aligned}
d_{k} & =\frac{0,9}{\max \overrightarrow{\mathbf{P}_{\mathbf{k}}}-\min \overrightarrow{\mathbf{P}_{\mathbf{k}}}} \\
a_{k} & =1-d_{k} * \max \overrightarrow{P_{k}}
\end{aligned}
$$

At the same time $\max P k$ corresponds to the minimum value of the indicator of road provision, and $\min P k$ - the highest value of the indicator of road provision from all the subjects of the Russian Federation under consideration. The value of "social priority" in the form of value is determined by the formula:

$$
\Delta N B_{t}^{P_{k}}=\left(\Delta C_{T P t}+C_{B N t)} * \overrightarrow{\boldsymbol{P}_{\boldsymbol{k}}}\right.
$$

Where $\Delta N B_{t}^{P_{k}}$ is the non-transport social effect that cannot be directly estimated in the year t, rub .; $\triangle C_{T P t}$ - effect in the form of reducing various types of costs and increase in net output at enterprises and organizations of transport in the year t, rub .; $\Delta C_{B N t}$ - effect in the production of goods, works and services and the social sphere, which can be directly estimated in the year $\mathrm{t}$, rub.

As for the amount of savings received by users when traveling on a toll road and road object compared to a free alternative route, its value, determined by the formula (3) [21], when multiplied by the correction factor is an indicator of "social priority". 
Thus, the mathematical interpretation of the author's model of the expert assessment process of the quality of the functioning of the traffic interchange in relation to the "smart city" system will look like (7):

$$
\left\{\begin{array}{c}
\frac{d(T R)}{d(t)}=\Delta N B_{t}^{P_{k}} * \widehat{\mathrm{P}_{k}}=\left[\left(\Delta C_{T P t}+C_{B N t)} * \overrightarrow{\mathbf{P}_{\mathbf{k}}}\right] *\left(a_{k}+d_{k} * \overrightarrow{\mathbf{P}_{\mathbf{k}}}\right) \rightarrow \text { Econ } \rightarrow\right. \text { max } \\
\frac{d(T R)}{d(u)}=\Delta N B_{t}^{P_{k}}=\left(\Delta C_{T P t}+C_{B N t)} * \overrightarrow{\mathbf{P}_{\mathbf{k}}}\right) \rightarrow \text { Cos } \rightarrow \max \\
\frac{d(T R)}{d(\lambda)} \rightarrow \text { Ecol } \rightarrow \min C d \\
\frac{d(T R)}{d(\lambda)}=\text { Psmart } k \rightarrow \text { Gef } \rightarrow \text { min Pg }
\end{array}\right.
$$

Thus, due to the lack of scientific provisions in the Russian Federation Transport Development Program of the transport system development parametric regulation, taking into account the requirements of the country economic system optimal change, in the context of its transformation into a "smart city" and recommendations for the development and implementation of an effective state economic policy in this direction, the authors of the article have developed a mathematical model for evaluating the efficiency of the traffic interchange functioning in the "smart city" system.

\section{Discussion}

The proposed author's mathematical model "Model of expert assessment of the quality of functioning of a "smart city" transport junction", makes it possible to describe in sufficient detail the procedure for assessing the quality of engineering solutions proposed for the development of the urban trunk interchanges transport system, as it focuses on all factors affecting the proposed interchanges high functionality at all lifecycle stages of the projects being implemented. For comparison, traditional transportation system development models have many shortcomings.

The comparative analysis of the transport systems development traditional models (local, regional, country model view) carried out by the authors revealed a lot of shortcomings (does not solve the problem of traffic congestion - poor logistics, All elements of the transport system are managed only within the limits of a separate agglomeration and do not allow building a common system for organizing and controlling transport operations), which can be the subject of widespread discussion, but it can be precisely ascertained that the process of modeling the development of transport systems is subject only to general geographical.

These results prove that the proposed author's model "Model of expert assessment of the quality of functioning of a "smart city" transport junction" allows you to level the shortcomings of their scientific predecessors and allows you to more systematically look at the problem of the transport sector, as the transport system is considered in this model, not by itself, but as an asset for the development of a "smart city".

\section{Conclusion}

At present, there is no modern methodological apparatus that allows reasonably and with a certain degree of reliability to take into account the influence of various parameters characterizing the socio-economic living conditions of a particular region of Russia on the magnitude of the overall effect of capital investments in transport infrastructure in the context of introducing the concept of a "smart city". To solve this problem, the social effect 
that is not amenable to direct valuation, the authors propose to determine indirectly by integrating the results of the three effects that accompany the functioning of any transport system of the "smart city": economic, environmental and budgetary. The author's developed mathematical model makes it possible at the parametric level to control these three effects in the context of the implementation of the "smart city" concept.

\section{References}

1. A.A. Volkov, Promyshlennoe i grazhdanskoe stroitel'stvo, 9, 4 (2018)

2. S. Musa, Academia, Jan (2016)

3. Federal'naya tselevaya programma "Razvitie transportnoy sistemy Rossii (2010 - 2021 gody) (Mintrans RF, Moskva, 2007)

4. Prognoz dolgosrochnogo sotsial'no-ekonomicheskogo razvitiya $R F$ na period do 2030 goda (Minekonomrazvitiya RF, Moskva, 2013)

5. Transportnaya strategiya Rossiyskoy Federatsii na period do 2030 g. (Mintrans RF, Moskva, 2008)

6. Programma deyatel'nosti Gosudarstvennoy kompanii "Rossiyskie avtomobil'nye dorogi" na dolgosrochnyy period (2010-2020 gody) (Mintrans RF, Moskva, 2009)

7. Strategiya sozdaniya seti avtomagistraley $i$ skorostnykh avtomobil'nykh dorog $v$ rossiyskoy federatsii do 2030 goda (Mintrans RF, Moskva, 2008)

8. Strategiya razvitiya Gosudarstvennoy kompanii «Avtodor» na period do 2030 goda (Mintrans RF, Moskva, 2014)

9. Rasporyazhenie Pravitel'stva RF ot 22 noyabrya 2008 g. № 1734-r (Kreml', Moskva, 2008)

10. D.Kharvey, Nauchnoe ob"yasnenie v geografii (Progress, Moskva, 1974)

11. M. N. Bogonosov, Otsenka sotsial'nogo effekta. pri obosnovanii effektivnosti stroitel'stva. avtomobil'nykh dorog (Izdatel'skiy Dom «Nauka», Moskva, 2016)

12. VSN 21-83. Ukazaniya po opredeleniyu ekonomicheskoy effektivnosti kapital'nykh vlozheniy v stroitel'stvo i rekonstruktsiyu avtomobil'nykh dorog (Transport, Moskva, 1985)

13. Rekomendatsii po uchetu vnetransportnogo effekta pri planirovanii seti avtomobil'nykh dorog (Minavtodor RSFSR, Moskva, 1980)

14. Rekomendatsii po planirovaniyu ocherednosti stroitel'stva i rekonstruktsii mestnykh avtomobil'nykh dorog s primeneniyem EVM (Minavtodor RSFSR, Moskva, 1985)

15. M.S. Panteleeva, S.M. Borozdina, MATEC Web Of Conferencies, 10608047

16. M.S. Panteleeva, S.M. Borozdina, MATEC Web Of Conferencies, 10608048

17. V.O. Chulkov, Infografija. Tom 4: Mnogourovnevoe infograficheskoe modelirovanie. Modul'ny jkurs lekcij (SvR-ARGUS, Moskva, 2007)

18. M.S. Panteleeva, S.M. Borozdina, MATEC Web Of Conferencies, 19301011 (2018)

19. M.S. Panteleeva, S.M. Borozdina, MATEC Web Of Conferencies, 19305006 (2018)

20. G.A. Polyakova, Ye.N. Ivanova, Osobennosti opredeleniya sotsial'noekonomicheskoy effektivnosti kapital'nykh vlozheniy $v$ zadachakh tekhnikoekonomicheskogo proyektirovaniya avtomobil'nykh dorog (MADI, Moskva, 1989) 21. A. V. Kats, Effektivnost' stroitel'stva avtomobil'nykh dorog mestnogo znacheniya (Transport, Moskva, 1980) 